\title{
Legal Education, International Strategies, and Rebuilding the Value of Legal Capital in China
}

\author{
Co-authored with Zhizhou Wang
}

As with Japan and South Korea, the founding of faculties of law and a Westernstyle legal profession in China came part and parcel with imperial pressures late in the nineteenth century (Kronche 2016: 67-68). Prior to that time, China provided the dominant model for national governance in the region. Indeed, between 1368 and 1841, China, Korea, Vietnam, and Japan had "maintained peaceful and long-lasting relations with one another" (Kang: 2010: 3), with China "clearly the dominant military, cultural, and economic power in the system" (3)-a "hegemon ... operating under a presumption of inequality, which resulted in a clear hierarchy and lasting peace" (3). Kang terms this a "tribute" system. It involved travel, educational exchange, and gifts, and the other countries "consciously copied Chinese institutional and discursive practices in part to craft stable relations with China" (3). As a result, "there was no intellectual challenge to the rules of the game until the late nineteenth century and the arrival of the Western powers" (3). China's rules dominated. As Zhang notes, "although the Qing had plenty of interactions with foreign law, it approached these interactions from a period of political and intellectual strength" (2019).

Western power became much more salient after that time. With the decline of the Qing dynasty late in the nineteenth century, some among the Chinese elite acquired Western educations or influences and essentially sided with the imperialists against the traditional Chinese system, which was hostile to law and emphasized mediation and dispute resolution by traditional Confucian elites. While the Japanese in the Meiji period drew on Europe and especially Germany, Koreans operated within the imposed Japanese system, and Indians built on their English 
legal education, Chinese elites internationalized in multiple directions, playing double games in their own interests, and pushing aside Confucian learning and governance. An internationalized legal elite was built at that time.

This new elite evolved into a blend of pro-Japanese, pro-American, proGerman, pro-Soviet, and state or commerce-oriented law graduates. They became a kind of legal oligarchy akin to the others we have examined in this book. This group and those following its habitus have reproduced and endured into the present day. They played a strong role in Republican China, and as Tiffert shows (2015), they continued to be important in the People's Republic of China (PRC). The challenges they have faced have been enormous, but after much pain and turmoil the descendants of this group are thriving in China today. Unlike the traditional bar in India, this group has adapted remarkably well to changes in Chinese society and changing global hegemonies. This makes it exceptional among the case studies. Of course, many of this group stayed with the Kuomintang military government in the 1940 and moved with it to Taiwan after the communist takeover, but clearly there was a group that stayed behind.

The greatest challenge to this group's existence was a strand of Maoist Communism linked to cadres mainly of peasant background, who sought to minimize their role and the cosmopolitan and international influences they represented (Tiffert 2015). After many individuals from the cosmopolitan elite spoke critically of the government during the "thousand flowers bloom period" in China, they were severely attacked during the "anti-rightist" campaign that followed in the late 1950s. The Cultural Revolution beginning in the 1960s was the zenith of power of the radical Maoists, with devastating consequences for the cosmopolitan elites.

The revival of law after Mao's death in 1976, and the development of legal education and legal institutions after the Cultural Revolution, is a remarkable testament to the resourcefulness and resilience of this group. Elite and globalized legal education, corporate law firms, and even the "rule by law" policies of Xi Jinping only make sense in relation to the persistence and reproduction of this elite. The story of the past forty years is not about increased liberalism or democracy, as the West had hoped in the 1990s, but rather about an increase in the domestic value of internationalized legal capital, which had suffered a dramatic decline during the Cultural Revolution (Zhang and Ginsburg 2019).

\section{LAW, INTERNATIONALIZATION, AND CHINESE INTELLECTUALS PRIOR TO COMMUNISM}

As elsewhere in Asia, the imperial powers of the nineteenth century that forced China to open up to trade and influence also exported and even imposed their Western legal ideas. Strong local elites in China, as elsewhere, began to invest in and promote foreign models of modernization. In particular, as the Qing dynasty 
declined and Japan ascended, Japanese influence became important. $\mathrm{Li}, \mathrm{Li}$, and $\mathrm{Hu}$ focus especially on the impact of China's defeat in the Sino-Japanese War (2018: 251). Zhang points to a combination of factors, including changes in Confucian ideology to favor more pragmatism and materialism, the Boxer Rebellion, and signs of material weakness, as undermining traditional Chinese values. As a consequence, "the goal of political and eventually social reform became, more or less, to be like the West" (2019: 231). Nationalists increasingly viewed the foreign concessions in China as a "major embarrassment" and pointed to them as "one of the major justifications for legal reform" (234). The incentives for foreign legal intellectual investments were strong: "During the last fifteen years of the [Qing] dynasty, the promotion of Western law and political institutions became a kind of calling card through which new faces could open up the gates of power at the center" (235). Zhang argues that this group of Chinese intellectuals was unique in its embrace of Western models: "Chinese elites came to condemn and vilify their own sociopolitical traditions with a zeal that has few parallels, if any, in Asiatic history" (230).

The elites adapted to the new context. The legitimacy of the Confucian intellectual elite had been built on academic achievement and, prior to the Republican period, performance on the imperial exam. Studies indicate that this legitimacy was not inconsistent with the fact that access to the elite was not equally available. According to $\mathrm{Wu}$, "those who succeeded in passing the merit-based examination came from only around 300 large families in selected regions during the Ming and Qing periods" (Wu 2017: 8). The mechanisms for reproducing this elite included the linkage of the exam contents to particular social worlds, in addition to more mundane ones such as the cost and expense of preparation (8; Elman 2013). Access to foreign ideas and education was similarly unequally distributed in favor of an elite that was able to capitalize on those assets (and many of them were undoubtedly descendants of the Confucian elite).

Reformers looked especially "to Japanese renderings of positivist German Staatsrechtslehre" (Tiffert 2015: xii; Zhang 2019), partly for convenience and partly because that approach to law was serving the Japanese state. Tiffert, like Zhang, emphasizes the radical nature of this shift away from Confucianism: "In imperial China, adjudication was part of a bursting portfolio of administrative responsibilities borne by local magistrates. ... Consummate generalists, they cultivated humanistic erudition and received no systematic legal education, as China had none to offer them" (10). A functioning criminal/judicial field had taken shape around the Mandarin scholar-bureaucrats, but it operated mainly to build up the relatively marginal position of those seeking to moderate strict criminal sentences handed down by powerful local bureaucrats (Bourgon 2000). These kinds of local materials could be used and built upon within major transformations. But according to Tiffert, who emphasizes the break, "Confucian ideology frowned upon lawsuits... The state restricted access to the courts, suppressed those who sought to facilitate litigation, and shunted most disputes to local elites and social organizations for mediation" (10). 
From Tiffert's perspective, the radical change to a new judicial system "wrecked that model and the relations of knowledge and power imbricated within it.... This was nothing short of a Big Bang in the universe of Chinese law," which, he argued, "went beyond even the 1949 revolution. . . . The entire infrastructure of legal education and judicial training had to be built on the fly while the courts and the law took shape around them" (11). That effort-and other foreign borrowings-had very mixed results over the course of the nineteenth and twentieth centuries, but all the while, the internationalized elite thrived.

Legal education as such began in China, with the most important influence "from the last years of the Qing Dynasty to the first years of the Republic of China" being the Japanese system ( $\mathrm{Li}, \mathrm{Li}$, and $\mathrm{Hu}$ 2018: 252). Indeed, "legal education in China then was merely a copy of that of Japan" (252). Professors also came from Japan: "From 1897 to 1909, law schools in China altogether hired 58 Japanese law professors" (253). This early tilt toward Japan (and derivatively toward Germany) was evident in the fact that, for example, "in 1915, the number of Chinese students in Japan exceeded 4,00o. Most of them chose the majors of law, politics and economics" (254). At that point very few studied law in the US-reportedly only sixty-one in 1918 (254).

Under the Republic of China, founded in 1912, law was pursued by students mainly because of the opportunity it provided to join the government bureaucracy (253). The Chaoyang Law School in Beijing, established early in the twentieth century, for example, was the best-known private law school and focused on training for the government, especially the judiciary (Kronche 2016: 121). Public law schools also produced mainly government officials.

The investment in foreign legal models was not limited to Japan. Macdonald's work on Chinese legal education, published in 1980, provides interesting detail on how internationalized the law department was at Peking University, founded late in the nineteenth century on the European model. In the 1920 it was "divided into French, German, and English sections. Students elected to study in one of these sections and became proficient in the corresponding language" (Macdonald 1980-81: 316). The Japanese influence was still strongest, but the emphasis on the "international" rather than the particular country is telling.

The impact of the United States began to be felt in the 1920s "with the worsening of Sino-Japanese relations" ( $\mathrm{Li}, \mathrm{Li}$, and $\mathrm{Hu} 2018$ : 257). The international legal influence on the Republic of China was evident in the fact that of the 2,448 qualified professors and associate professors recognized by the Ministry of Education between 1941 and 1944, more than 1,900 had studied abroad, including 934 who had studied in the United States (257). There was a "transition from the Japanesestyle legal education to the American-style legal education" (257).

The private school in China most influenced by the United States was the Comparative Law School of China, established in 1915 near Shanghai by American missionaries as the law school of Soochow University (Connor 1994). The name itself reflected the internationalization of the legal field. That school focused on 
producing private lawyers and maintained close ties with the United States: "Most of its instructors came from the University of Michigan, and the majority of students sent abroad went to New York University ... [but] spread around the globe" (Kronche 2016: 121). More than 1,200 students had graduated by 1946 , and " 72 of them took teaching positions in various Chinese universities (four of them took the position of dean), 21 became judges and 72 worked for the government" (Li, $\mathrm{Li}$, and $\mathrm{Hu}$ 2018: 257).

The US influence also increased the size of the private bar in the major cities, including a commercial and corporate bar, especially in Shanghai, where the graduates merged with foreign counterparts that had begun to cluster around trade and the Mixed Court of Shanghai (Kronche 2016: 175). Also important was the relationship between the United States and the Kuomintang. Building on the long relationship between US missionaries and their lawyer allies with China, a number of influential individuals and groups in the United States saw the KMT as the great hope for building the rule of law in China (175-77). Chinese actors to some extent manipulated that faith, playing to US missionaries while not rocking the boat with the KMT, whose activities were more politically instrumental. Kronche notes the US approaches were kept alive also by a group of Chinese lawyers whose "personal capital in China was based on" their foreign (specifically US) expertise (176).

The picture is of a still quite small legal field coexisting with and evolving with foreign influences prior to the communist takeover. Some of the best-known members were foreign-educated, and they influenced others in the Western-oriented legal field of the Republican era. Foreign legal capital helped build careers, academic programs, and reforms even if the reforms were relatively superficial and the legal field had little autonomy. Since social capital was not invested deeply in legal capital, the orientation of the legal field could shift relatively easily in response to political changes. This flexibility has been key to the survival and success of this internationalized legal elite.

\section{LEGAL ELITES AND CHANGE UNDER COMMUNISM THROUGH THE CULTURAL REVOLUTION}

The communist victory in the Civil War brought another major shift. All preexisting law was abolished, and many of those central to the legal system fled with the KMT to Taiwan. This time the shift was toward the Soviet Union and its version of Marxist law. The new government under Mao Zedong in 1949 promoted the policy of "learning all from the Soviet Union" (Li, Li, and Hu 2018: 254). According to Li, $\mathrm{Li}$, and $\mathrm{Hu}$, "law was regarded by the ruling party of China as an important instrument to realize its socialist modernization. Therefore, the communist government decided to redesign its legal education based on the former Soviet Union model and to reconstruct its law schools and departments" (255). Here were the latest 
foreign-inspired recipes for modernization. ${ }^{1}$ Tiffert in fact relates this embrace to the "habit to transplant first and sort out later" that began in the nineteenth century (2015: xii).

The Law Department of Renmin University was the most prominent facilitator of the move toward Soviet-modeled law. There were four teaching units: "the Unit of State and Legal Rights Theory, the Unit of State Law, the Unit of Criminal Law, and the Unit of Civil Law. Each unit consisted of Russian experts, translators and Chinese teachers" ( $\mathrm{Li}, \mathrm{Li}$, and $\mathrm{Hu}$ 2018: 255). Renmin's graduates were "the main source of teaching and research staff in all other universities and research institutes" as well as teaching materials (255). Importantly, the government also retained law departments at six universities: "Chinese People's University [Renmin], Northeastern People's University, Beijing University, Wuhan University, Fudan University and Northwestern University" (Han and Kanter 1984: 546). By 1956 there were reportedly "2,824 new law students . . . ten times the enrollment figure in 1949" (548).

Institutes of Political Science and Law, modeled on the Soviet Union, also became central to legal education in the 1950s. In 1952 and 1953, a number of such institutes combined to form the East China Institute of Political Science and Law, the Beijing Institute of Political Science and Law, the Central Southern Institute of Political Science and Law, the Southwestern Institute of Political Science and Law, and the Northwestern Institute of Political Science and Law (Han and Kanter 1984: 546).

The descendants of the cosmopolitan legal elite had a strong presence. The Soviet Union's new influence did not fully displace other influences in classrooms. $\mathrm{Li}, \mathrm{Li}$, and $\mathrm{Hu}$ quote a graduate from that time saying that "points of different textbooks were contradictory to each other. ... They used the Russian textbooks which were full of the descriptions of class struggle. Some others might have been labeled as 'extreme rightists' as they admired the constitutional politics, democracy and the rule of law, including the independence of the judiciary of western countries, without any criticism" (2018: 256).

Tiffert argues that one reason for this continuity was that the Communist Party prior to the victory had sought legitimacy linked to the intellectual elite long valued in China (2009). The Chinese Communist Party thus "assiduously courted intellectuals, appealing to their self-image as successors to China's imperial scholar-officials, their patriotism and their frustrated ambitions to undertake national salvation. . . . It welcomed them back into politics with promises to revitalize China and to usher in an age of multi-party New Democracy" (10). Many (we do not know the number) did go to Taiwan with the Kuomintang, but a significant number remained in the PRC.

As a result, "even high-ranking officials and judges of the former regime with no apparent leftist sympathies, such as the brilliant Yang Zhaolong, head of the Criminal Section of the Republican Ministry of Justice and protégé of Roscoe 
Pound," joined to "contribute to the building of 'New China"' (10). This had a strong impact on the writing of the constitution of 1954. Leading participants, according to Tiffert, included "Shen Junru, the first President of the Supreme People's Court of the PRC, who earned the highest jinshi degree in the Qing imperial examinations of 1904, studied law in Japan, was a Republican era leader of the Shanghai Bar and the China Democratic League" (4). Another was "Qian Duansheng, Harvard Ph.D., close friend of John Fairbank, and a leading Republican-era constitutional scholar who served as the first post-1949 Dean of the Beijing University School of Law and founding President of what is now the China University of Politics and Law" (4). Finally, he points to Wang Tieya, discussed below, who was a student of Harold Laski and a renowned scholar of international law (4). ${ }^{2}$

Tiffert's recent work seeks to generalize further (2015). He argues that the PRC was "an heir (rather than ... an antithesis) to Republican judicial modernization" (xxvi). Communist legal history thus amounted to "a dynamical system composed of shifting equilibriums" that allowed the PRC to tap into "an unheralded wellspring of diversity in PRC legal policy and practice" (xxvi). The Communist Party from this perspective was a mix of peasant cadres and members of the intellectual class, and one consequence of this mix was that legally trained elites from the Republican era were part of what constituted the Communist Party as well as the state. Those elites had adapted to promote the position of law through the importation of socialist legality into the new PRC.

Some of the literature suggests that individuals from the pre-communist legal profession began to face purges early in the communist period. But there are also many suggestions of continuity; for example, "lawyers, mainly holdovers from the previous regime, began to practice in state-run legal advisory offices" (Gelatt and Snyder 1980-81: 1). Noteworthy here is that Qian Duansheng became the first president of the China University of Politics and Law. Certainly, there was tension "between law-trained specialists (many of whom were trained in the West) or intellectuals and new cadres who 'lacked legal skills and knowledge', but were ideologically reliable" (Han and Kanter 1984: 549; Li 1980). Such tensions generated conflicts from the start, but the early period gave an influential place to the intellectuals.

The Maoist emphasis on mediation became one source of tension, both symbolically and in practice. Ironically, according to Tiffert's research, the emphasis on mediation was one example of a party staple that evolved out of practices set in motion by the Nationalist-trained legal elites. The shift in mediation practices toward a more communitarian approach, partly to allay court congestion, came through Li Mu'an, "one of China 's earliest modern graduates and procurators, and a pioneer in the establishment of the Republican Bar" (2015: 51). According to Tiffert, Li Mu'an's 1942 reform as president of the high court of the Shaanganning border region opened the way to "popular mediation." This was initially promoted as a "new institution of border region judicial policy for educating the people to 
listen to reason and to do good, preserving peace among humanity." Later, "party rectification radicalized the atmosphere and inflamed class struggle." Prior to Li Mu'an's reform and its adaptation, "mediation occupied a small and neglected corner of CCP judicial practice" (59).

Mediation came to symbolize the divide between the legal reformist elites. Communist peasant cadres were suspicious of the cosmopolitan intellectuals. They tended to take an anti-intellectual stance against elites, whose minds were supposedly too corrupted to adapt. Mao, who tended to favor this group, supported this party-organized mediation against the legal programs favored by the Republican-trained elite (Tiffert 2015). While very different from traditional Chinese mediation, it served as a symbol of local approaches taking the place of Western-oriented law.

The position and value of the now Soviet-inspired law shifted with the political breezes, with the Cultural Revolution the culmination of the rejection of law and the zenith of the attack on, among others, the internationalized legal oligarchy, however flexible its members sought to be. According to Tiffert, "in the domain of law, the CCP bore multiple, competing visions of the revolution simultaneously, and as the balance of forces in the surrounding environment shifted, different equilibriums among these visions emerged, tracing a convoluted, sometimes violent course that reaches the present day" (2).

It is instructive to apply this perspective to an article in the American Journal of Comparative Law co-written by Han Depei and Stephen Kanter in 1984. It is written partly in the first person by Han Depei, who is discussed in more depth below. Looking back from 1984, the article defends the earlier work of the legal profession: "By 1956, then, a legal educational system basically suited to the needs of New China had been established and had achieved initial success" (1984: 548). The embrace of the Soviet model was deemed a success: "In reforming the old legal educational system and establishing the new during this period, our guiding ideology was clear, our principles and policies were comparatively correct, the measures adopted were reliable, and consequently the results were satisfactory. The graduates that came out of the institutes and departments of political science and law during this period have become the backbone of our country in politics, law and legal education" (548). The position of law and legal training was relatively strong at that moment. Indeed, Gelatt and Snyder (1980-81: 45) refer to the period as a "legal renaissance," Jerome Cohen termed it a "golden age" of law in China (quoted in Gelatt and Snyder 1980-81), and more recently Tiffert called it a "brief flowering of law" (2009: 25). All of this suggests that this flexible elite group of intellectuals felt able to thrive in a new legal context, this one modeled by the Soviet Union.

But the renaissance ended quickly: “By the late 1950's, however, everything changed. Legal scholars and practitioners had been among the first to take advantage of Chairman Mao Zedong's call in the spring of 1956 to 'let a hundred flowers 
bloom.' They had demanded more independence in their work and had gone as far as to challenge Party direction of the legal system. However, their outspokenness led to a quick backlash. Denounced as bourgeois rightists, many of China's small corps of legal experts were transferred to the countryside to be 'reeducated through labor"' (Gelatt and Snyder 1980-81: 42). A number of law professors spent "ten or more years [working] in the fields of village communes" (Murphy 1982: 51). The anti-rightist campaign led to the Cultural Revolution, at which point began the further persecution of legal intellectuals.

Han Depei, the co-author of the article on the changes in the aftermath of the Communist takeover, was part of that reform process after the revolution. $\mathrm{He}$ exemplifies a certain type of cosmopolitan intellectual of the time. He was born in 1911 in Jiangsu province, graduated from the law department of Nanjing University in 1934, and obtained a master's degree in law from the University of Toronto before taking up studies in international law at Harvard Law School in 1942. He became a professor in the Law Department of Wuhan University in 1945 and later the dean of the that department. As the co-authorship in 1984 indicates and as discussed below, he among others was active in the law revival of the late 1970s. He reportedly led the task of restoring academic prowess to the law department at Wuhan University in 1979 (Academy of Humanities and Social Sciences 2020).

Han describes the impact of the leftward shift in the late 1950 as follows: "Our department, one of the few law departments retained after liberation, was merged in 1958, together with the Central-Southern Political and Legal Cadre School, into the law department of Hubei University. Most of our teachers were transferred to other posts and some of our books and reference materials were taken away. The enrollment figures of students in law departments registered a sharp decrease throughout the country" (Han and Kanter 1984: 551). The situation then got worse: "In 1964 classroom studies were replaced by participation in the 'four clean-ups' movement (a movement to clean things up in the fields of politics, economics, organization and ideology), and law courses were soon abolished. By then it had already been announced that class struggle must be stressed year after year, month after month, and day after day" (552).

Even prior to the Cultural Revolution, then, "most of the professors who had studied old laws had been driven down from the rostrum, while newly trained teachers of law were forced to change their profession. Teachers and students who had been labeled 'Rightists' in the Anti-Rightists struggle bore continuous oppression. Law graduates were mostly assigned to posts in out-of-the-way places, unable to apply what they had learned. The youth of this period regarded law study as a dangerous road to take and naturally stayed away from it" (552).

Legal education came to a halt during the Cultural Revolution: "All the institutes of political science and law were also shut down, with the single exception of Southwestern Institute of Political Science and Law, which survived in name only. School buildings were seized and books and reference materials were divided up" 
(554). Han and Kanter emphasized the remarkable devaluation and destruction of legal capital: "Advanced legal education, which had contributed to the training of law experts for our revolution and construction, suffered extremely serious damage. A thousand-strong contingent of law teachers built up painstakingly after liberation was dispersed and only a little over a hundred were left." (554).

\section{REVIVAL AFTER THE CULTURAL REVOLUTION: \\ THE RETURN OF THE LEGAL ELITES \\ AND INTERNATIONAL STRATEGIES}

As the Cultural Revolution waned in impact and higher education returned, "the law departments-not surprisingly in view of the particularly suspect classification of legal workers during the 'period of turmoil'-were the last to reopen their doors after China's educational hiatus" (Gelatt and Snyder 1980-81: 45). Peking University reopened its law department on a limited basis in 1974, two years after other undergraduate departments opened up again (44). By 1980, Peking law department enrollment had grown substantially, to about seventy (45). What is significant is that, as with respect to Han, most of the faculty were scholars who had studied law in China or abroad before communism, "participated in the legal renaissance of the 1950's and suffered the hardships of the anti-rightist movement and the Cultural Revolution" (45).

In 1978-79 the situation changed more dramatically. The four modernizations proclaimed at that time by the party did not include law but provided an opening for law. This renewed interest in developing the legal system reflected a new faith "that successful rapid modernization would be impossible without such a system" (Han and Kanter 1984: 556). At that time, there were very few professors available to teach law. According to the same article, "most highly qualified legal educators are elderly and are presumably nearing the end of their active careers" (561). Han, for example, was then seventy-three: "China is therefore in a race with time to train a new generation of law teachers, researchers and legal workers before the current fragile core of expertise disappears" (561).

The creation of the new law department at Wuhan University, for example, involved these relatively few pre-communist holdovers. Narrating again in the first person, Dean Han stated: "It was restored in August 1979. Surmounting all kinds of difficulties, we enrolled sixty undergraduates in the summer of 1980 as law majors, another fifty nonresident students in a branch school, as well as two graduate students of international law. . . . In 1981, we recruited 100 undergraduates as law majors and 32 as international law majors. In addition, thirteen graduate students were enrolled. The Department now has over fifty teachers and scientific research workers" (561).

At Peking Law School, according to one interviewee, there were classes on Western laws and legal systems, taught by Gong Xiangrui; as well as a course 
on comparative constitutional law, taught by Shen Zonglin; and another taught by Wang Tieya on public international law. These were offered as plain introductions to laws and legal studies in the West, and they allowed students to see China from a new perspective that inspired interest in the West (Int. 12-China). According to the same interviewee, the individuals who took up these teaching positions as the law schools reopened were valued for their educational capital-for their experience of studying law abroad and for the comprehensiveness of the legal education they had received (Int. 12-China).

By 1980, then, those legal elites who had survived the Cultural Revolution, including Dean Han, had become leaders in the revival of legal education in China (Li 1980: 226). Tiffert in fact notes that the cosmopolitan group that was influential in producing the 1982 constitution overlapped considerably with those who had worked on the 1954 constitution: "Much as they had twenty-seven years before, the Party's political elites again engaged constitutional specialists, Qian Duansheng among them, for guidance on how to cement this shift, restructure the state, and lay the foundations for stable economic growth" (2009: 25). The 1982 constitution, he writes, "provided the space for jurists such as Chen Shouyi, Jiang Ping, Li Buyun, Qian Duansheng, Wang Tieya and Zhang Sizhi-all of whom had either participated in the drafting of the 1954 Constitution or came of age in the brief flowering of law it spawned" (25). Tiffert cites their role in helping "to restore the legal and legislative machinery of the state, to reconstitute the legal profession, rebuild legal education and, in time, to reopen suppressed debates on marketization, democracy, the rule of law and human rights" $(25) .^{3}$

The revival included the universities as well as the larger law departments of the Institutes of Politics and Law, which had closed in the 1970s. A Chinese professor who has studied the revival of legal education after the Cultural Revolution noted the high quality of this first group of senior professors (Int. 2-China): “They were 'really good' with legal education from places like 'Harvard and Paris' and expertise in, for example, 'Roman Law."' A number of them, as noted earlier, had international reputations prior to the Communist Revolution. This group trained the new generation of professors who would staff the law schools in the 1980 s and '9os. Since the first law Ph.D. in post-Cultural Revolution China was awarded only in 1986 or 1987 , the early faculty members from the new generation possessed only LL.B.s. Teaching materials were scarce. According to the same source, the early faculty typically knew German from their studies and Russian from the post-Revolution period, but their English generally was not strong (Int. 2-China). Many of the books they used were copies of Taiwanese texts that brought a mix of US and German/Japanese influence (Li, Li, and Hu 2018: 254).

As had their predecessors, these professors promoted international strategies that fit their own experiences and the need for allies in support of legal education and the legal profession. Jerome Cohen, for example, writes that "from the very start of the Open Policy in 1978-79, Chinese people have been eager to study 
law in other countries" (2010: 274). There was considerable exchange with the United States during this period. We have a good account of the relationship with Columbia Law School (Edwards 2009). Columbia began focusing on China in the early 1970s under the leadership of R. Randle Edwards, hired in 1973 on the recommendation of Jerome Cohen, then at Harvard and a key figure in US-China academic and professional relationships. Edwards traveled to China in 1978 under the auspices of a friendship program, and he reportedly met three law professors at Peking University-Wang Tieya, Rui Mu, and Guo Shoukang (Edwards 2009). He described their enthusiasm for an international program:

The professors told us that the law faculty had just been reopened, after being closed for twelve years during the Cultural Revolution. They expressed keen interest in establishing exchanges with Columbia Law School and other American law faculties, when I broached the subject. On my return to Columbia, I followed up with invitations to all three of the Peking University law professors I had met on my first full day in China, and all of them visited the Law School more than once in the coming years. I discovered that one of them, Professor Rui $\mathrm{Mu}$, was an "old friend" of Columbia, having held the status of Visiting Scholar at Columbia Law School from 1946 to 1948 . (6)

The faculty members whom Edwards met initially exemplify the contribution of the already internationalized legal elite to the post-Cultural Revolution revival of law and legal education and the internationalization that went hand in hand with that revival (Minzer 2013: 351). One result was that, in the 1980s and 9os especially, Chinese legal academia once again became highly focused on the West-specifically, in this period, on the United States. This influence extended from preferred models of graduate legal education to the specific content of legal academic research.

The careers of the three professors whom Edwards met are interesting and informative. Rui $\mathrm{Mu}$ went on to revive his distinguished scholarly career, as summarized below:

Born in a wealthy merchant family in Shanghai, he studied in the most modern
"Western-style" school at that time. He was eloquent in English, French, and Ger-
man, and proficient in Russian and Latin. After getting his Master of Law from
the University of Paris and his doctorate from Frankfurt University, he went back
to China serving as a law professor at National Southwest Associated University,
later as deputy dean of the Peking University Law Department, and founding direc-
tor of the Institute of Economic Law and the International Economic Law Institute.
Though being marginalized during the "Cultural Revolution" (1966-76), he was
immediately filled with energy after the reform and opening up, and laid the basis
of two disciplines-economic law and international economic law in New China.
(Peking University 2011)

We have an entry on Wang Tieya in Wikipedia that suggests a very similar background: 
Wang Tieya was educated at Tsinghua University and the London School of Economics. He began his career as Professor of International Law at the National Wuhan University (1940-1942) and National Central University (1942-1946). In 1946, he moved to Beijing University. After 1949, he became one of the leading authorities on international law in China along with Li Haopei, one of his classmates in London. Wang was legal advisor to the PRC delegation to the United Nations in 1950 and the Third United Nations Conference on the Law of the Sea in 1979. During that time, he was Chairman of the Political Science Department (1947-1952), and Head of the Section on International Law at the Faculty of Law (1956-1983). In 1983 Wang became the founding Director of the International Law Institute of Beijing University. (Wang 2020)

Guo Shoukang was born in Tianjin in 1926. He graduated from the Peking University law department and became a professor in the 1940s. He became the leading intellectual property scholar in China after the 1970s. He had studied at Columbia University, Georgetown University, the UCLA School of Law, and the Max Planck Institute for Industrial Property. Reportedly, "he is also the sole expert having participated in drafting the three important IP [Intellectual Property] laws, Patent Law, Trademark Law and Copyright Law, and is widely acclaimed as one of the founders of IP legal system of new China" (Nie 2010).

Taking advantage of their foreign contacts and newly established exchange programs, this generation of professors sent a number of their top students to study abroad. Several notable legal scholars in China today were early graduates of Peking University's law school. One is Zhu Suli, who has served as Dean of the Peking Faculty of Law. He is the importer of Posnerian economics into China (Int. 3-China) and "probably the best-known Chinese legal theorist in the West" (Seppänen 2014: 85). He is considered the founder of neoconservative legal theory in China (89). He graduated in 1982, obtained a Ph.D. from Arizona State, and attended an LL.M. program at McGeorge Law School. He reportedly was a soldier and a civil servant prior to enrolling in the Beijing law program (Peking University School of Law 2020). Despite his international background and expertise, he is known as anti-Western and as a leftist in the Chinese context (Upham 2005).

Another is Ji Weidong, who graduated in 1983 and planned to attend graduate school in the United States. Instead he went to Japan, where he earned a doctorate from Kyoto University. He served as a professor at Kobe University before returning to Shanghai to become Dean of the KoGuan Law School, Shanghai Jiao Tong University, in 2008. He was involved in the reform of legal education in Japan, and his scholarship has embraced a strong law and society dimension. He is the editorin-chief of the Asian Journal of Law and Society. His writings today focus on legal proceduralism (Seppänen 2016: 125-27).

A number of graduates of this period are leaders of the state today. They participated in the same educational environment. For a notable example, Li Keqiang, the current Chinese premier and the second most powerful individual in China, 
studied law at Peking University from 1978 to 1982 before obtaining a Ph.D. in economics. According to Cheng Li, a scholar who studies China's ruling elites,

during his college years, academic and interdisciplinary study groups were very popular at Peking University, which had a long tradition in liberal arts education. Li actively participated in various public lectures and debates organized by these groups and studied under Professor Gong Xiangrui, a well-known British-educated expert on Western political and administrative systems. Li was particularly interested in the subjects of foreign constitutional law and comparative government. Li and his classmates translated important legal works from English to Chinese, including Lord Denning's The Due Process of Law and A History of the British Constitution. (Li 2016: 128)

At that time Peking University was deemed the center of liberal legal studies, with Renmin its conservative counterpart, but individuals at these schools and the institutes of political science and law did not always conform to the image of their respective schools (Int. 12-China). For instance, studies of civil law thrived in Renmin under the leadership of Tong Rou, who advocated for increasing the focus on civil society and private law. By contrast, at Peking Law School, in economic law Rui Mu focused on a more vertical state/market relationship (in opposition to the horizontal relations among private actors). Similarly, Wang Jiafu, who was in charge of the Law Institute of the Chinese Academy of Social Science (CASS) - an official think tank serving the ruling party - was well-known for his advocacy for a legal system that concerned itself solely with the civil/private relationship. And Jiang Ping, the former president of the China University of Political Science and Law (CUPL), which had been founded to train party cadres as well as legal officials who were loyal to the regime, made the school one of the most liberal in the country-its students joined in the Tiananmen Square movement in 1989 (Int. 12-China). Our list is of course incomplete, but we do want to show that this pluralism within institutions was consistent more with the legal field's overall focus on internationalized legal learning than on the particular orientations of scholars. This allowed the field to shift in tandem with shifts in political and economic orientation among those in state power.

Returning to the exchange programs beginning in the late 1970 s and early 1980s, the exchange programs with Columbia and other institutions produced many prominent investment bankers and business lawyers. The Ford Foundation facilitated many of these exchanges. Edwards (2009) has noted that "many of the Chinese J.D. and LL.M. graduates from the 1980s and 9os now occupy leadership positions in American investment banks and in private Chinese and American law firms. Among them, notable graduates include Wei Christianson (J.D.), currently the managing director and CEO of Morgan Stanley in China; Charles Li (J.D.), CEO of Hong Kong Exchanges and Clearing, and formerly the chairman and CEO of JP Morgan China, and Wei Chun (LL.M.), who is now a partner in the Beijing office of Sullivan \& Cromwell" (8). ${ }^{4}$ 
These examples are consistent with the fact that the elite of legal academia and the graduates produced by the leading universities were internationalized from the start, well before communism. They suffered during the Anti-Rightist Campaign and the Cultural Revolution but were able to step into leadership positions after the return of legal education and the legal profession. This, we should note, does not mean that their focus is solely on international connections and approaches, nor, as in Zhu Suli's example, does it mean they support foreign models. Their international orientation is not inconsistent with publishing in Chinese with the aim of getting the ear of the Chinese state, even if to oppose foreign models.

\section{THE LEGAL FIELD TODAY: THE GROWING STRENGTH OF THE INTERNATIONALIZED LEGAL ELITE IN STATE AND SOCIETY}

\section{Legal Education: Stratification and Adaptation}

Legal education and the legal profession have grown dramatically since the 1980 os. The same can be said to varying degrees about the other countries examined in this book. Indeed, law in China became one of the most sought-after majors before what Minzner describes as a readjustment from overproduction (Minzner 2013). The number of law faculties reached more than 6oo. The profession was once dominated by state employees, whereas today, private law firms play a major role in economic and political relations. There are now at least three "grades" of law schools in China today. One group comprises the elite university law schools that have been for the most part internationalized from the start. These schools provide continuity with the past through the cosmopolitan professors who taught law prior to and after the Communist Revolution and who trained a new generation to follow in their footsteps. They include familiar names such as Peking, Renmin, and Fudan. Second are the institutes of political science and law, which can be traced to the Russian influence after the communist takeover. They are much larger in terms of student bodies and number of faculty members. We have some good information on their place today, but not as much data as we have on the elite schools. The third group includes the vast number of law schools that exist outside the major cities. We know very little about their faculties and students and, more generally, the roles that they play locally and nationally. There is some evidence that they are struggling to find places for their graduates. ${ }^{5}$

\section{The Elite of Legal Education}

The rapid expansion of law, and of higher education generally, "significantly increased the internal stratification in the Chinese law school community and intensified the interschool competition for government support and recognition" 
(Wang, Liu, and Li 2017: 243). The period of law school expansion corresponded with the rise of "law schools affiliated with elite universities that used to specialize in natural sciences and engineering" (245). The rapidly rising law schools of Tsinghua University, Zhejiang University, and Shanghai Jiao Tong University, for example, benefited from their universities' "administrative ties with the Ministry of Education, rich alumni resources, and dedication to strengthening humanities and social studies in the state-led effort to build 'comprehensive research universities"' (245). They caught up with their "traditional elite counterparts," such as the law schools of Peking University and Renmin University (245). Global rankings have reinforced the position of the traditional elite and the newcomers in the Chinese educational hierarchies.

The elite law schools are also considered to be the most focused on theory, today as in the past: "Universities such as Peking, Tsinghua, Nankai and Wuhan were more traditionally focused on producing legal academics, researchers and public servants, so practical education was seen as less important" (Biddulph 2010: 270). They remain dominated by highly theoretical lectures. According to one recent study, "no law school is willing to define its mission as the "training of practitioners"' (Zhao and Hu 2012: 354). Accordingly, "practice experience is not given much weight in the recruitment and promotion of law professors" (354). Scholarly publication is much more important than teaching in terms of career development. As a result, "faculty members in Chinese law schools lack incentive to invest in improving legal teaching" (354). Legal theory is at the core of these schools.

There is a movement to develop clinical legal education. More than 100 law schools now offer clinics of some kind, and an organization called the Chinese Committee of Clinical Legal Educators keeps up with developments in this system. The Ford Foundation was instrumental in launching a number of these programs (354), which are now found in the full range of law schools. Lawyers in the United States often view these clinics as central to legal education reform and as key to building the rule of law in China (e.g., Phan 2005). Those ambitions have not been realized.

The founder of the first clinic, at Wuhan University in 1980, Wan Exiang, earned an LL.M. from Yale Law School in 1987 through the Ford Foundation exchange program and has followed a remarkable path since then. He became professor of international law at the Wuhan University law school and is currently the Deputy President of the Supreme Court of the PRC, a member of the standing committee of the CPCC, and Vice-Chairman of the China Society for Human Rights Studies. His career is consistent with the fact that the clinics in China have added a more US-inspired element to legal education, but this is an add-on that has not affected China's hierarchical values and approaches more generally.

Finally, while difficult to classify according to Chinese internal hierarchies, we mention the highly innovative and internationalized Peking School 
of Transnational Law in Shenzhen. Founded in 2008 as a domestic initiative to provide Chinese students with an alternative to studying abroad, STL hired a prestigious founding dean from the United States and aspired to produce graduates with US JDs suitable for them to be hired by global law firms. As a result of US opposition, it failed in its goal of achieving accreditation by the American Bar Association; the school then retooled to offer both a Chinese JM and a US JD in one four-year program. With its international faculty, the school is more like one of the Hong Kong law schools than a Chinese law faculty. Despite not offering the LL.B., it has found a niche in China and has placed its 100 to 150 annual graduates in international and Chinese corporate and in-house positions. It hopes to inspire further reform in China. Its creation and survival is another indicator of China's openness to the international in legal education.

As noted earlier, the elite Chinese law faculties are highly internationalized and theory-driven. Faculty are recruited from those with advanced degrees from China or abroad, with very few from practice: "Many elite Chinese law schools have adopted the hiring policy that, except for exceptional applicants, graduates with only domestic law degrees are not considered in faculty recruitment" (Wang, Liu, and Li 2017: 260). Those who have gone abroad since around 2000 have divided their graduate studies between the civil law-mainly in Germany and France-and the common law-mainly in the United States (Int. 5-China). Accordingly, there are divisions in the law schools between those that emphasize the more practical learning and interdisciplinary approaches of US law schools and those that embrace the legal formalism identified with German approaches (Int. 4-China; Wang, Liu, and Li 2017: 253). Such differences in background may be part of the reason why some schools, such as Peking Law School and Shanghai Jiao Tong, have more of an interdisciplinary focus. An informant from Renmin noted a competition between schools that emphasize dogmatic law (i.e., the German influence) and those that lean more toward the social sciences (i.e., the US influence) (Int. 4-China). One professor at another leading school said that in the current situation, editors might criticize an article for relying on too many US sources and not enough on German ones (Int. 5-China). What unites the various groups is a focus on legal theory, even if what is seen as legal theory from a German perspective is very different from what legal theory means from a US perspective. The range of theoretical perspectives is suggested by Seppänen, who characterizes the literature on the rule of law as a "theoretical smorgasbord" (2016: 66).

The shifting debates in legal scholarship provide a sense of how the internationalized legal academy responds to shifts in the state. According to Zhang (2019), "for much of the 1980s and early 1990s, both American and German trained scholars shared a basic consensus that Chinese law should become more like foreign legal systems. They differed in which foreign legal system they preferred-for obvious and often self-interested reasons, each side preferred the legal system they were educated in-but most people seemed to agree that Chinese law needed to westernize once more and pursue a rights-based ideal of the 'rule of law"' (246). 
Zhang highlights a relatively recent shift in the dominant approach of the USeducated scholars. Late in the 1990s, he suggests, a "growing number of American trained scholars, most notably Zhu Suli, dean of Peking University Law School between 2001 and 2010, began to explicitly argue against transplanting either American or German law, or any foreign legal system. Instead, they argued that China needed to find its own path" (247). Accordingly, "by the 20oos, the most visible opponents of westernization tended to have some sort of American academic background" (247). Most interestingly, "certain strands of American legal and political theory were especially conducive to this agenda" (247). Zhang cites law and society scholarship, various forms of critical legal studies, sociology, and economics as Western tools to "deconstruct and delegitimize the application of Western law to other societies" (247).

Academic developments thus "allowed Chinese leftists to reject the notion of universal human rights and argue for Chinese cultural and political exceptionalism" (247). These Western-based academic theories, more generally, "gave academic voice to a political mainstream that, while still very much in control of the actual levers of power, had become somewhat dormant in intellectual discourse" (248). The "state swiftly moved to support this trend, boosting the sociopolitical profile of its major advocates and enlisting their support in a number of major legislative moves" (248). The new theories fit the new politics in China. What is noteworthy is not that the legal academy shifted to accommodate a new balance of power. The chapters of this book and the theory of legal revolutions demonstrate the importance of such shifts in maintaining the position of law. What is remarkable in China is how internationalized the debates and the people participating in them are.

Cosmopolitan professors from the elite law schools circulate internationally and develop substantial networks abroad. They naturally play a double role similar to the role that elite Chinese law scholars and professors played in the past. They import from abroad and reshape for domestic purposes, and this links Chinese legal professors with global markets and hierarchies even while they adapt them to Chinese interests and the field of state power. They can modify their behavior for the different contexts. Chinese scholars at times encourage those abroad to see progress or at least ferment toward "the rule of law with Chinese characteristics"; at home, they are more conservative. For example, Li Buyun, one of the cosmopolitan jurists mentioned by Tiffert in regard to the drafting of the 1982 constitution, has been a leader in speaking and publishing in favor of the "autonomy of the law" (Seppänen 2016: 121), rights protection, and the rule of law within and outside China, even though his politics within China are relatively conservative (121).

An important feature of the present day is that the Communist Party now signals which scholars it sees as favorable to party orientations (Int. 12-China). Especially since the mid-199os, scholars have been invited to lecture the top party leaders in Zhong Nan Hai, the hub and central headquarters of the Chinese ruling party's most senior leaders. It appears that those who are chosen to give these lectures-without any official statement as such-enjoy significant prominence 
on the basis of their political recognition by the ruling party; their careers may well blossom as a result (Int. 12-China). This treatment may also distinguish those who are loyal to the party from those who tend to disagree with it and thus gain its disapproval.

Finally, the risks that elite and cosmopolitan legal scholars face more generally are mediated by their international stature, their valued scholarly capital, and their connections to the worlds of economic and political power, whereas other legal professionals are not as protected. As shown by Liu and Halliday (2016), the lawyers who run the greatest risk of retaliation by state organs are the ones without academic credentials or ties to the state. In particular, lawyers for criminal defendants may run huge risks with few resources except the hope that media publicity will persuade the political authorities to take their side.

For aspiring students, the top law schools fit into a system of education in which "China's elite colleges are the fundamental point of entry for the scientific and political elite" (Yang and Chen 2016: 196). The number of openings is quite small, especially given that the undergraduates at the top schools-those who gain their position from national test scores-are the most favored. Peking Law School has about 2,000 students (700 undergraduates), Tsinghua has about 1,300 (300 undergraduates), and Shanghai Jiao Tong University KoGuan Law School even fewer, some 725 (220 undergraduates). Renmin Law School has some 3,000 students (80o undergraduates). These and a few other elite schools graduate a very small percentage of the more than 200,000 law graduates per year (Minzner 2013). The elite group is quite rarified.

In 1993, the Ministry of Education and Ministry of Justice began to consider creating a degree akin to the US graduate JD degree. According to Ji Weidong, writing in 2005, this was part of a plan to introduce the US way of legal education (2005: 15), with the US business lawyer as a model. The plan also drew some inspiration from the US-inspired Japanese move to replace the undergraduate LL.B. degree with the graduate JD. In 1998 the JM degree was created, and there was optimism that it would become the main vehicle for training practicing lawyers in China (15; Erie 2009: 67).

Predictably, it has not been successful. Erie writes that "so while the JM is being designed as the main degree for professionalizing PRC lawyers, in fact, the LL.M. [following the LL.B.] remains a more efficacious vehicle of professionalization. This is particularly true in terms of developing practical skills of legal reasoning, argumentation, and oral advocacy" (95). One professor noted that the JM is not a "good education" but that it "makes a profit" (Int. 6-China). The LL.B. followed by the LL.M. remains dominant.

The most respected students are those who score highest on the national exams and get into the most selective universities. A JM graduate does not get that kind of respect. Erie notes, for example, that "international law firms show a preference, in hiring first year associates, for students who obtained an LL.B. at the undergraduate 
level and then either went on to obtain an LL.M. in China or abroad. Domestic firms also prefer LL.M. graduates" (Erie 2009: 75). The continued importance of the first degree, where selection is based largely on the national exams, reinforces the significance of the law school hierarchy as compared to a more practical law degree modeled on the US JD.

The strategy of the Chinese elite universities, including the newer ones such as Shanghai Jiao Tong University KoGuan Law School, has therefore been to focus on the very small number of students they accept for LL.B. degree programs while also offering the JM in order to generate revenue and as a means to upgrade the less prestigious undergraduate degree. Having learned from the JD's relative failure in Japan, the dean at KoGuan, Ji Wedong, has reinforced the elitism of undergraduate education. He has created a $3+3$ program that enables about fifty of the top undergraduates to move into an academic master's program along with the LL.B. He also sought philanthropic support to invest further in the quality of the faculty and student body, and has received some \$30 million from Leo KoGuan, an American/ Chinese entrepreneur. In this way he has made the elite training at his school even more selective.

According to professors at the top schools, the students of the "top ten" all come from similar family backgrounds (Int. 5-China; Int. 6-China) and forge similar careers (Wang, Liu, and Li 2017). Students come largely from the best secondary schools in the cities, and their parents have assets to invest in education. Thus, Tsinghua has fewer students from rural backgrounds than in the past (Int. 6-China). The students' backgrounds as reported by the professors and deans are consistent with more general recent sociological research on Chinese mobility. There is some mobility, to be sure, but the statistics make it clear that those with the advantaged backgrounds are strongly favored.

Xiaogang $\mathrm{Wu}$, in a recent study of mobility and education in China, found that "family background directly affects access concerning the quality of college education. Other things being equal, upper-middle-class and upper-class children clearly enjoy advantages in getting into elite and other 211 universities" (roughly a top 100 based on a project of educational reform from 1995: 2017: 27). There are also advantages to coming from more urban and politically significant communities-most crucially, from "keypoint high schools," that is, those schools that especially feed the leading universities (27).

Another recent article augments this picture by showing that cadre status also plays a role: "the political status of a cadre parent is significantly correlated with the possibility of his or her child attending an elite college" (Yang and Chen 2016: 209). Again, the most important factor is access to the keypoint high schools that feed the top colleges. There is upward mobility through the relatively meritocratic system organized around the national tests, but, as these studies note, there is a family cadre advantage as well as one of resources: "approximately 30 percent of students in the elite universities came from upper- or upper-middle class families, 
whereas the percentages in other 211 universities and non-211 universities are 18.6 percent and 14.6 percent" (Wu 2017: 17).

The combination of local meritocratic, international, and perhaps in recent years familial capital is increasingly evident in the legal academy. One leading China expert noted that "although the intergenerational reproduction of academic legal elite in China was severely undermined by the Cultural Revolution and other political events in the Mao era, since the reform era, it has gradually re-emerged." This scholar reports seeing "an increasing number of children of distinguished Chinese legal scholars pursuing doctoral degrees in law, and some of them already hold faculty positions. It is likely that in the next 5-10 years a wave of 'secondgeneration law professors' will emerge in the Chinese legal academy, as happened in many other places" (email China-1).

\section{The Institutes of Political Science and Law}

The importation of Soviet models in the 1950 s led to the creation of five Institutes of Political Science and Law to go with the European-inspired law departments of Peking, Renmin, Jelin, and Wuhan. The story of the relationship between the two groups is complex; that said, the relationship is more a division of labor than a competition (Wang Liu, and Li 2017; Minzner 2013). There are also overlaps and combinations and movements between the two types of law schools. A recent article on Chinese leadership, for example, notes that the justices of the Supreme People's Court of the PRC in 2013 ( $\mathrm{Li} \mathrm{2014}$ ) included four graduates from the Southwest University of Political Science and Law in Shanghai, three of whom had advanced degrees from Peking Law School; one from the Chinese University of Political Science and Law in Beijing; one from Jilin University and Peking Law School; and one who only graduated from Peking Law School. These judicial positions seem to link more to the schools of political science and law designed to train prosecutors and judges.

The Institutes of Political Science and Law, as noted, were modeled on Soviet schools and were meant in the first place to train loyal legal cadres for judicial and prosecutorial positions. The universities and their law departments, in contrast, were originally created to mimic the great Western (and Japanese, based on Western) universities. The division of labor in these early years is significant; however, enduring hierarchies in the legal field meant that both kinds of faculties of law sought to build the credibility of law through foreign models. Also, there was some circulation of elites when these schools were established.

After the Cultural Revolution, the basic division of labor returned as the schools reopened. According to Herman, writing in 1982, "graduates of the university law departments are educated primarily for careers in research, teaching and government. The institutes, on the other hand, are geared to train practicing lawyers to serve in the procuratorates, the Ministry of Justice and the public security organizations (police), as well as to serve in the roles of advocate and justice" (1982: 
792). Sarah Biddulph's close study of the East China University of Political Science and Law, published in 2010, notes also that 30 percent of the graduates at that time "were allocated to the legal divisions of local governments, a range of government departments, and [other organizations]" (2010: 263). Furthermore, "schools within the Ministry of Justice system were traditionally more oriented toward practice as many of the graduates of these schools were employed in the state's judicial organs, as judges, prosecutors, police, justice officials and lawyers" (270). These institutes were thus closely linked to national and local government legal bureaucracies.

The institutes are much larger than the elite law schools. The Chinese University of Political Science and Law in Beijing has 14,00o students (8,00o undergraduates). The school likely graduates at least 1,00o undergraduates with LL.B.s. The East China University of Law and Political Science reportedly graduates 1,500 undergraduate LL.B.s per year (Int. 5-China). They do not have the same prestige as the more theoretical law departments, a partial exception being the Chinese University of Political Science in Law, which has close ties to the Ministry of Justice (China email 1) and has internationalized through a relationship with the European Community.

From the perspective of one who attended the East China University of Law and Political Science and has had experience with the faculty, it is a "different world" (Int. 5-China). Those who attend that university do not have near the scores on the national exam that the students at the elite law schools have. Graduates tend to go into criminal litigation or seek ("self-select") to be judges or prosecutors, rather than lawyers for state-owned enterprises (SOEs) or corporate law firms. Teaching is focused more on the bar examination. The students tend to be less eager to go abroad after graduation - "to take the TOEFL" - than those in the elite schools. The students generally are "traditional" and "stay in China" (Int. 5-China). They also tend to be from the provinces, and their future careers typically depend on family capital brought from home and connected to local networks of judges and prosecutors (a "family sector") (Int. 5-China).

The power of these schools is in general less internationally based, involves less scholarly capital, and is more tied to rank-and-file governmental and party power.

\section{The Rank and File Law Schools and Law Students}

There is reportedly a scramble to get jobs among students outside the very small elite of graduates from the top law schools and others with family or guanxi connections that facilitate recruitment. Those who practice criminal law, for example, have little in common with the elite law graduates (Liu and Halliday 2011-12: 838). It is suggestive that $\mathrm{Li}, \mathrm{Li}$, and $\mathrm{Hu}$ (2018) quote one student as stating that "our teachers told us in class that if there were no judges or government officials in our family members, we should not choose law schools. Law is the major for the 
people with power. The children from poor families will not have a bright future after graduation" (2018: 22).

A great number of graduates compete for a relatively small number of positions within the prosecutors' offices and the judiciary. Minzner thus writes (2013: 360) of a "spiral of degree devaluation," where "many Chinese law students are willing to spend large sums of money on advanced degrees to distinguish themselves from other graduates. Enrollment in foreign LL.M. programs (with tuition ranging up to US $\$ 50,000$ a year) has surged. Chinese schools have expanded their J.M. . . . programs, charging four times as much in tuition per student as compared with the 'academic' master's degrees." Graduates of many, perhaps most, of the Chinese law schools may not enjoy the study-abroad option that Minzner suggests makes a difference. In addition, as we saw in Japan and Korea, the difficulties facing lawyers at the low end of the hierarchy have become a reason to put pressure on the low-prestige schools. One goal of recent reforms in China has been to cut down and essentially defund some of the more marginal law schools. As elsewhere, this has threatened the law schools that are more accessible to less privileged students (Minzner 2013: 374).

\section{The Rise of Corporate Law Firms and Their Dominance by the Internationalized Elite}

The Chinese corporate legal market has a short history, one that began in 1992 as a top-down initiative to mimic institutions of globalization. Corporate law firms, as elsewhere in Asia, make up a tiny percentage of the legal profession. In late 2017 there were more than 340,00o lawyers in China (Liu 2020). The small number of corporate lawyers stands out: "modelled on global law firms from Britain and the United States" in the early 1990s, "the elite club of the corporate bar is relatively easy to identify" (Wang 2018). Since it has been well-studied in several respects (especially by Sida Liu), our discussion of it will be brief.

China now has its Red Circle of law firms, comprising "a dozen elite Chinese corporate law firms such as King and Wood (today's King and Wood Mallesons), Jun He Law Offices, Haiwen and Partners, Jingtian and Gongcheng, and Zhong Lun Law Firm" (53). The largest of these has more than 4,0oo lawyers. Beijing has the greatest number, but firms are also concentrated in the major cities of Shanghai, Shenzhen, Guangzhou, and Hangzho. There are also small boutique firms, and law graduates also work in the SOEs, which increasingly emphasize the need for quality in-house counsel (Liu 2020).

Drawing from the expertise of Chinese lawyers educated abroad and with work experience in global law firms, the Chinese law firms now compete from a very strong position for high-end work with the more than 100 global firms (Liu 2020) in China-most of which are in relatively small "outpost offices" (Stern and Li 2016). The Chinese firms have advantages in part because Chinese lawyers are not authorized to practice local Chinese law in international firms, which limits 
local recruitment. Another reason, which is only beginning to be studied in depth (Wang 2018), is the importance of connections to the Chinese government and regulatory structures. Wang writes that for a variety of reasons, there is a "growing interaction between the Chinese state and Chinese corporate lawyers" (63). We discuss this strengthening connection below.

The elite law firms hire according to the educational hierarchy, despite the fact that elite schools focus on theory and not practice. The Peking Law School, in particular, reportedly pays little attention to the bar examination, and the graduates who take it-likely to qualify for litigation-reportedly do worse than the national average. One informant from Peking Law School, perhaps exaggerating, said that the professors there, in fact, are proud to "teach the opposite of bar exam, and the students score poorly-2o percent of the 10 percent who take the bar examination pass" (Int. 7-China). According to one student at a top school, it is "easy" for the LL.B. graduates to get positions at the corporate law firms if they want them (Int. 3-China). Students from the "mediocre" law schools, however, have no chance.

Firms in Beijing, for example, reportedly recruit mainly from Peking Law School, Tsinghua, and the University of International Economics and Business (Zhu, Zhao, and Liu 2020). The Peking Law School, historically the most prestigious school, reportedly dominates in the corporate law firm sector. Very few of its graduates reportedly go into litigation (Int. 7-China). Criminal law especially is looked down upon (Int. 7-China; Liu and Halliday 2016). Other positions sought by the elite graduates are in the government and the SOEs.

The new arrivals to elite law status, including notably KoGuan and Tsinghua, are competing with their more established rivals by taking the lead in the globalization of faculty recruiting, stronger scholarly requirements, and educational programs, but the others have followed the same strategy (Wang, Liu, and Li 2017). Wang, Liu, and Li maintain that the enhanced international strategy relates to "the prestige and wealth of corporate law," which "prompt[s] law schools to develop courses, curricula, and internship opportunities tailored to the careers of international business lawyers. Accordingly, the ability to place graduates in prestigious law firms is becoming a new symbol for the success of law schools and a key attraction in law schools' recruitment of college applicants" (243). The easiest access is for those with an elite undergraduate legal education, who follow up with LL.M.s, especially from abroad (Zhu, Zhao, and Liu 2020). The internationalized law faculties thus operate in sync with the corporate law firms and SOEs in China.

\section{The Increasing Value of Legal Capital in Governance and the State}

The value of legal capital in China has increased over the past forty years. The historically high value of elite and internationalized legal capital has returned, and it is rewarded in governmental and party careers as well as with positions in law firms and SOEs. Cheng Li's detailed recent study of the Chinese ruling elite 
highlights this change. He notes the shift in the educational credentials away from technocrats such as engineers, "with the so-called rule of the technocrats lasting for only about two decades" (2016: 203). The well-connected and talented children who took the path of legal and related training have been rewarded. Chinese leaders are known more today "for their educational and professional training in the social sciences, economic administration, and law" (203). These leaders invest their legal learning and capital in state governance, distinguishing themselves from those with other claims to party and governmental power. As suggested below, they quite naturally also link to the elite law graduates in corporate law firms and elsewhere.

The increased value of legal capital in governance is well explored in a recent article by Zhang and Ginsburg (2019), who point out that this change is not the same as an increased commitment to the liberal legal values, which seemed to be on the ascendency in the 1980 s and '9os. Zhang and Ginsburg do not note any shift in the training and expertise of key Chinese leaders, but they make a persuasive case that there has been a shift toward law: "contrary to conventional accusations that China has 'turned against law, Chinese politics have become substantially more law-oriented over the past 5 years, and . . . several core legal institutions, including the judiciary and the Constitution, are now more politically significant than at any point in the 69-year history of the People's Republic of China (PRC)" (2019: 309). This conclusion, they note, is not inconsistent with increasing central control by the top party leadership around President Xi Jinping. The move toward greater control at the top, they note, has been implemented "legalistically." The increasing role of law involves, among other things, "empowering courts against other state and Party entities, insisting on legal professionalism, and bringing political powers that were formerly the exclusive possession of the Party under legal authorization and regulation" (310). The changes go with more independence of the judiciary, higher pay, and the related ability to attract more talent into the judiciary.

Zhang and Ginsburg observe that prior to Xi Jinping's rise, there was a reaction to what was seen as excessive foreign-inspired legal liberalism. This led to a relatively brief and ineffective attack on law reminiscent of the dramatic attacks of the Cultural Revolution and earlier by party activists (2019). Citing Minzner's work (2013) on the "rise and fall" of legal education, they note that under President $\mathrm{Hu}$ Jintao, Xi Jinping's predecessor (2002-12), this reaction "included a de-emphasis on formal law and court adjudication, and the subjugation of judicial power to political imperatives" (Zhang and Ginsburg 2019: 318). In their words, "instead of formal law, the Party sought to promote mediation as the preferred means of resolving social disputes, indeed as an institutional embodiment of the 'Harmonious Society' promoted by President Hu Jintao" (318). "As part of a general program to increase the courts' responsiveness to 'the feelings of the masses, judges were 
systemically evaluated on the percentage of their cases - the more the better-that were either mediated or voluntarily withdrawn" (324).

This focus on mediation, they note, was not very popular with the Chinese public, which by then had little interest in activist mediation as opposed to law. Indeed, Zhang and Ginsburg affirm the respect of the public at large toward law, courts, and the constitutions - all of which can be traced significantly to the internationalized legal elite that the Anti-Rightist Campaign and Cultural Revolution attacked. The neo-Maoist rally against them under the banner of popular mediation appears to have been defeated. The party's further distancing itself from the populism of the Cultural Revolution is one of many signs of the revival of the internationalized legal elite in the state and the economy.

\section{Elite Legal Education, Corporate Law firms, and the State}

The literature on corporate law firms and elite faculties of law notes that graduates of the elite faculties, including now especially law, occupy strong positions in the party and state. This chapter has offered several examples of graduates prominent in the state as well as in law firms. We do not, however, have a literature on personal relationships from family, school, or career between, for example, partners in corporate law firms and leaders in government. We know little, for example, about how governmental careers are converted into corporate law or whether the reverse takes place. We do have a growing literature, mentioned earlier, that emphasizes that the success of Chinese corporate law firms and their advantage over international law firms with offices in China often come from government relationships (Wang 2018).

An intriguing preliminary report by Lawrence Liu (2019) has explored some of these connections, focusing especially on the vast Belt and Road Initiative (BRI), first announced in 2013. Commenting on the growing outbound investment that characterizes the (BRI), he notes that "PRC legal professionals are increasingly relied upon to advise domestic industries, broker deals with foreign companies and states, and handle the disputes that arise in challenging foreign legal environments" (2019:1). Significantly, the Chinese state takes an active interest in this role, seeking "to implicate lawyers in the political dimensions of China's outbound efforts" (2). Liu explores efforts by the Ministry of Justice (MoJ) and the All China Lawyers Association (ACLA), beginning in 2012, to "cultivate a group of PRC cross-border legal experts" (2) and to build a government-recognized elite in the service of these transactions (see also Stern and Liu 2020).

Accordingly, "the ACLA and the MoJ jointly selected a talent pool of 300 lawyers with foreign legal expertise. . . Over four years . . the program aimed to produce 120 lawyers proficient in the corporate transactional work involved in outbound investment" as well as in various other transnational specialties. This effort has been expanded, again reflecting the high expectations placed on lawyers, 
who have been called upon in a governmental document to, among other things, "serve as good legal advisers to the government," to "promote positive economic and trade exchanges," and to "help Chinese companies go out, and defend their rights and interests abroad" (2).

What is especially interesting is that in 2017, again according to Liu, the ACLA announced a list of "BRI and Cross-Border Legal Experts" (2). Liu was able to examine the characteristics of the eighty-four PRC lawyers officially recognized as part of that group. The results are striking. First, they are mostly men. Second, there is a very strong representation from among the Red Circle firms: "A handful of lawyers have even moved to these law firms since 2017 . . f further consolidating the strength within these firms" (4). Third, "the overwhelming majority of "BRI and Cross-Border Legal Experts" hold advanced degrees (88 percent), with most of them pursuing graduate-level education abroad (60.6 percent)" (4). Fourth, they have strong ties to the party and government: "About 68 percent of these ACLA-recognized individuals hold leadership positions at some level of the bar association, and about 20 percent serve as People's Congress or People's Political Consultative Congress deputies" (5). Over 50 percent are party members, according to the lists available for Beijing and Shanghai.

These data, while preliminary, suggest three findings consistent with this chapter. First, the Chinese government today values the characteristics identified with the internationalized legal elite, high-level education (especially with study abroad), and strong foreign experience. Second, the largest law firms-staffed by such persons-have been identified as a key place to find the most elite lawyers. Finally, the government contemplates a major role for these elite lawyers along with the government in law and development, dispute resolution, contract management, and other aspects of the Belt and Road Initiative. All of this is consistent with a strong role for elite lawyers and law in the BRI as essential to the Chinese state strategy globally and at home. It also appears, as with respect to law professors, that the government today is more open about its efforts to find and identify allies with governmental strategies (which is consistent with governmental efforts to link lawyers to party ideology in bar exams and elsewhere: Stern and Liu 2019).

\section{CONCLUSION}

The internationalized elite that emerged in the late nineteenth century is thriving today after a remarkable story of challenge, adaptation, and survival-all the while making internationalized legal capital central to the process. Many were persecuted during the Anti-Rightist Campaign and Cultural Revolution, but they have returned to their previous social place. Their survival strategy was to emphasize elite, learned, and meritocratic education; to develop international expertise and contacts; and to legitimate a kind of post-Confucian elite that could occupy leading 
positions in the state and economy. The legal field in China is organized around a diverse group of internationalized scholars united by their commitment to legal theory and the value of international capital. The elite is also well-connected to state power. Learned law represents a kind of neutral space, and the different foreign and domestic emphases of the various contending groups have allowed the center of gravity to shift with the times and with changes in the orientation of state power. The new era of legalization has abandoned the almost pro-democracy and liberal teachings of the 1990 s to emphasize anti-corruption along with higherquality and better-paid prosecutors and judges, more judicial autonomy, less tolerance of dissent, and a greater focus on rewarding lawyers and scholars seen as best oriented to the party's agenda (Zhang and Ginsburg 2019).

Law appeared to return from out of nowhere after the Anti-Rightist Campaign and the Cultural Revolution. The law schools had all been closed, there was no legal profession, and lawyers were among those singled out as targets of the Cultural Revolution. It seemed at that point that there was no legal establishment to point to, in contrast to the situation in the other Asian countries studied in this book. But a new start developed out of the remnants of an internationalized elite, which revived its connections abroad, especially to the United States, and imprinted its approaches in the elite university law schools. This is a prime example of a revival of an elite, internationalized, and relatively meritocratic legal oligarchy akin to what we have seen in other Asian countries.

That elite has survived and adapted to changes in the state and the market as well as in global hegemonic relationships. This group helped make elite corporate careers the province of relatively privileged graduates, who typically study abroad after their initial work experiences. The faculty of the top law schools circulate globally, with impacts on both sides of the ocean. The internationalized faculty brought China into the global legal world of the WTO, international law, and international institutions (Roberts 2017), while also steering the international rules so as to be more in favor of Chinese concerns and interests. Elite graduates have now been assigned key roles in China's new Belt and Road Initiative, which will define China's relationship with much of the world.

China's situation is thus very different from India's, for example, where there is an entrenched conservative legal elite tied to the long experience of the British Empire, and from South Korea's, where the Japanese colonial legacy and the Cold War produced a deeply conservative legal establishment that resisted approaches identified with US-style globalization and the spread of large corporate law firms. The even more entrenched Japanese legal establishment is also sharply different from China's. China has various colonial legacies in law, all active prior to the communist takeover. But the genesis and history of this group has prevented it from acting as a conservative or entrenched legal establishment.

Interestingly, this internationalization has made the Chinese legal field over the past forty years seem more like Hong Kong than the other case studies in this 
book. The value and convertibility of international legal capital are quite high in both places. The law professors and law schools in China have much higher status than in Hong Kong. China did not inherit the British system seen in Hong Kong and India, which devalues law professors as mere teachers. In addition, Hong Kong, long a colonial entrepôt, tends to open up elite corporate law positions more to those educated abroad rather than to locals educated at Hong Kong law schools.

In China, as elsewhere, finally, a key part of the story is the growing gap between the small number of elite careers, students, and schools and the mass of schools producing many more graduates with slim prospects. Thus the relationship between Peking Law School, Tsinghua Law School, and others with the corporate law firms is very similar to what we find in South Korea or Japan. Also similar is the importance of the undergraduate school attended. The competition favors those with resources in a variety of ways, including in relation to the cherished opportunity to study abroad. 